\title{
ABSTRAK \\ HUBUNGAN FAKTOR FISIK KIMIA LINGKUNGAN DENGAN \\ KEANEKARAGAMAN LAMUN (seagrass) \\ DI PERAIRAN PANTAI DESA SULI
}

\section{Prelly. M. J. Tuapattinaya, Dosen Prodi Pendidikan Biologi UNPATTI, Ambon, 085243766957, email: frelly tuapattinaya@yahoo.co.id}

Daerah yang ditetapkan sebagai lokasi pengambilan data adalah Perairan pantai Desa suli Kabupaten Maluku Tengah, pada zona intertidal (stasiun I) dan zona subtidal (stasiun II). Pengambilan sampel dilakukan dengan menggunakan metode transek. Hasil penelitian menunjukan bahwa lamun yang ditemukan pada perairan pantai Desa Suli sebanyak 7 jenis. Indeks keanekaragaman jenis Lamun pada zona intertidal sebesar 1,45 dan zona subtidal sebesar 1,22. Kondisi faktor fisik kimia lingkungan (suhu berkisar antara $27-30{ }^{\circ} \mathrm{C}$, salinitas berkisar antara $29-33 \%$, pH berkisar antara 7-8,4 dan tingkat kecerahan air laut 0,5-6 m). Hasil ANAREG linear berganda terdapat hubungan yang signifikan secara simultan antara fakor fisik kimia lingkungan (suhu, salinitas, $\mathrm{pH}$ dan tingkat kecerahan air laut) dengan keanekaragaman, lamun di perairan pantai Desa Suli. Faktor fisik kimia lingkungan perairan yang memberikan sumbangan effektif tertinggi terhadap keanekaragaman lamun adalah faktor kecerahan air laut.

\section{Kata kunci: keanekaragaman lamun, fisik, kimia lingkungan}

\section{RELATIONS FACTOR PHYSICAL CHEMISTRY ENVIRONMENT WITH THE SEAGRASS BEDS (SEAGRASS) IN COASTAL WATERS VILLAGE SULI}

The area defined as the location of the data capture is the coastal waters of Central Maluku district Suli Village, in the intertidal zone (station I) and subtidal zone (station II). Sampling is done by using the transek method. Results of the study indicate that seagrass found in Suli Village coastal waters as much as 7 types. Index of diversity of intertidal zone of seagrass at 1.45 and subtidal zones amounted to 1.22. Condition of physical chemistry environmental factors (temperature ranging between $27-30{ }^{\circ} \mathrm{C}$, salinity ranges between $29-33 \%$, pH range between $7-8.4$ and level brightness of the sea water 0.5-6 m). ANAREG multiple linear results found a significant relationship between simultaneous physical chemistry factor environment (temperature, salinity, $\mathrm{pH}$ and the degree of brightness of the sea water) with 
diversity, seagrass in Suli village in coastal waters. Physical-chemical factors of the aquatic environment which gives the highest effective contribution to the diversity of seagrass was a factor in the brightness of the sea water.

Keywords: diversity, seagrass, physic-chemical, enviromental

Padang lamun adalah ekosistem oleh lamun yaitu mulai dari lumpur pesisir yang ditumbuhi oleh lamun sampai batu granitik. Namun pada daerah sebagai vegetasi yang dominan. Lamun dimana terjadi bioturbasi yang tinggi (Seagrass) adalah kelompok tumbuhan akibat aktivitas organisme bentik seperti berbunga (angiospermae) yang berbiji udang, moluska dan cacing, kerapatan tertutup (Angiospermae), berkeping populasi lamun dan spesies pioneer tunggal (monokotil) dan mempunyai akar cenderung berkurang bila dibandingkan rimpang, daun, bunga dan buah. Jadi dengan padang lamun yang tumbuh di sangat berbeda dengan rumput laut sediment karbonat yang berasal dari (Azkab 1999). Lamun mampu hidup patahan terumbu karang. Syarat lainnya secara permanen di bawah permukaan air untuk pertumbuhan lamuan adalah adanya laut (Sheppard et all, 1996). Komunitas sirkulasi air yang membawa bahan lamun berada di antara batas terendah nutrient dan substrat serta membawa pergi daerah pasang surut sampai pada sisa-sisa metabolisme. Dibeberapa daerah, kedalaman 8-15 meter dan 40 meter, padang lamun tidak dapat berkembang sepanjang dapat dijangkau oleh cahaya dengan baik karena tidak terlindung pada matahari (Den Hartog, 1970 dalam Dahuri 2003). Padang lamun yang dijumpai di alam sering berasosiasi dengan flora dan fauna akuatik lainnya seperti: algae, moluska, ecinodermata, dan berbagai jenis ikan.

Persyaratan dasar habitat padang lamun adalah perairan dangkal, memiliki substrat yang lunak dan perairan yang cerah. Hampir semua tipe substart didiami saat air surut dan juga membutuhkan intensitas cahaya yang cukup tinggi, maka padang lamun tidak dapat tumbuh pada perairan yang dalam, kecuali perairan sangat jernih dan transparan (Ertfemeijer, 1993 dalam Dahuri 2003)

Padang lamun memiliki peranan ekologis yang sangat penting, yaitu sebagai tempat asuhan, tempat berlindung, tempat mencari makan, tempat tinggal 
atau tempat migrasi berbagai jenis hewan. Komunitas lamun secara fisik di perairan laut dangkal membantu mengurangi tenaga gelombang dan arus, menyaring sedimen yang terlarut dalam air dan menstabilkan dasar sedimen (Kiswara dan Winardi, 1999). Lamun memiliki sistem perakaran yang kuat dan dapat mengikat sedimen sehingga dapat berfungsi sebagai penangkap sedimen dan unsur hara, pencegah erosi dan pelindung pantai. Lamun yang telah mati, serasahnya merupakan sumber nutrient bagi organisme bentik yang hidup disekitar substratnya. (Wood et al dalam Yauw 2001).

Hutomo (1997), mengemukakan bahwa walaupun beberapa kerja sama penelitian tentang lamun antara Indonesia dengan negara lain telah dilaksanakan, namun kajian tentang komunitas lamun di wilayah perairan pantai Indonesia tetap masih kurang memadai jika mengingat bahwa Indonesia memiliki padang lamun yang luasnya beribu-ribu meter persegi. Sebaran geografi lamun dalam skala makro telah diketahui namun masih banyak yang belum terinventarisasi termasuk kajian tentang keragaman lamun dan hubungannya dengan faktor fisik kimia lingkungan. Salah satu perairan pantai di Maluku yang memiliki komunitas padang lamun adalah Desa Suli.

Desa Suli merupakan salah satu desa di kecamatan Salahutu Kabupaten Maluku Tengah, yang terletak di pesisir pantai. Perairan pantai Desa Suli berhadapan dengan selat yang memisahkan antara Pulau Haruku dan Pulau Seram. Hal ini menyebabkan perairan pantai Desa Suli mendapat pengaruh langsung dari laut Seram yang masuk melalui selat tersebut, sehingga memungkinkannya mendapat pengaruh arus pasang surut yang cukup intensif. Walaupun demikian, dengan bentuk adaptasi morfologi lamun berupa bentuk perakarannya yang tertanam dan merambat pada substrat dasar perairan, dan didukung dengan tipe substrat dasar perairan yang didominasi oleh substrat pasir berlumpur dan karbonat, menyebabkan komunitas lamun dapat tumbuh dengan baik pada perairan tersebut Penelitian ini dilakukan untuk mengetahui hubungan faktor fisik kimia lingkungan dengan keanekaragama lamun (Seagrass) di perairan pantai desa Suli”. 


\section{METODE PENELITIAN}

\section{Tempat dan Waktu Penelitian}

Lokasi penelitian pada perairan pantai Desa Suli. Pencuplikan data dilakukan pada zona intertidal (stasiun I) dan zona subtidal (stasiun II) seluas $20.000 \mathrm{~m}^{2}$ dari keseluruhan luasan padang lamun di perairan pantai Desa Suli $\pm 600.000 \mathrm{~m}^{2}$. Penelitian telah dilakukan pada bulan Januari - Pebruari 2014. Penelitian ini merupakan penelitian deskriptif untuk mengungkapkan informasi tentang hubungan faktor fisik kimia lingkungan dengan keanekaragama lamun (Seagrass) di perairan pantai Desa Suli

\section{Teknik Pencuplikan Data}

Pencuplikan data lamun dilakukan dengan metode transek linier kuadrat dengan menggunakan petak cuplikan berukuran 1 x $1 \mathrm{~m}^{2}$. Garis transek dibuat pada setiap stasiun pengamatan dengan panjang $50 \mathrm{~m}$. Garis transek diletakan secara vertikal dari

$$
H^{\prime}=-\sum P_{i} \ln P_{i} \quad \operatorname{dimana} P_{i}=\frac{n_{i}}{N}
$$

\section{Keterangan:}

$H^{\prime} \quad$ : Indeks keanekaragaman Shannon

$n_{i} \quad$ : Jumlah individu semua jenis ke-i

$N \quad$ : Jumlah total semua jenis dalam komunitas

$P_{i} \quad$ : Kelimpahan relatif

$\Sigma \quad$ : Jumlah spesies individu garis pantai menuju laut, dimana jarak antar transek adalah $20 \mathrm{~m}$. Jumlah garis transek yang digunakan pada penelitian ini adalah 10 transek pada masing-masing stasiun. Petak cuplikan dibuat dengan ukuran 1x1 $\mathrm{m}^{2}$ dan diletakan sejajar dengan garis transek. Jumlah petak cuplikan pada setiap transek sebanyak 5 buah dengan jarak antar petak cuplikan adalah $10 \mathrm{~m}$. Dengan demikian jumlah petak cuplikan pada masing- masing stasiun sebanyak 50 buah. Data yang dicuplik adalah data biotis (jenis-jenis lamun dan indeks keanekaragaman lamun)

\section{Analisis Data}

Untuk mengetahui indeks keanekaragaman lamun maka data biotis yang diperoleh kemudian dianalisis untuk menentukan: indeks keanekaragaman jenis lamun di perairan pantai Desa Suli dengan rumus Shannon - Wiener sebagai berikut.

(Sumber: Ludwig and Reynolds, 1988)

$$
\begin{aligned}
& \text { Untuk menentukan hubungan } \\
& \text { antara faktor fisik-kimia lingkungan } \\
& \text { (suhu, salinitas dan pH air laut) dengan }
\end{aligned}
$$


keanekaragaman lamun pada perairan pantai Desa Suli maka data dianalisis dengan jenis analisis regresi, memiliki syarat pengujian, yaitu jenis datanya rasio atau interval, data berdistribusi normal, dan varians antar sampel homogen (Sugiyono, 1999).

\section{HASIL PENELITIAN}

1. Suhu
Hasil pengukuran terhadap suhu air laut pada perairan pantai Desa Suli menunjukkan bahwa suhu air laut pada zona intertidal berkisar antara $28-30^{\circ} \mathrm{C}$ sedangkan pada zona subtidal berkisar antara $27-28^{\circ} \mathrm{C}$. Perbandingan rata-rata pengukuran suhu pada zona intertidal dan zona subtidal dapat dilihat pada Gambar 1.

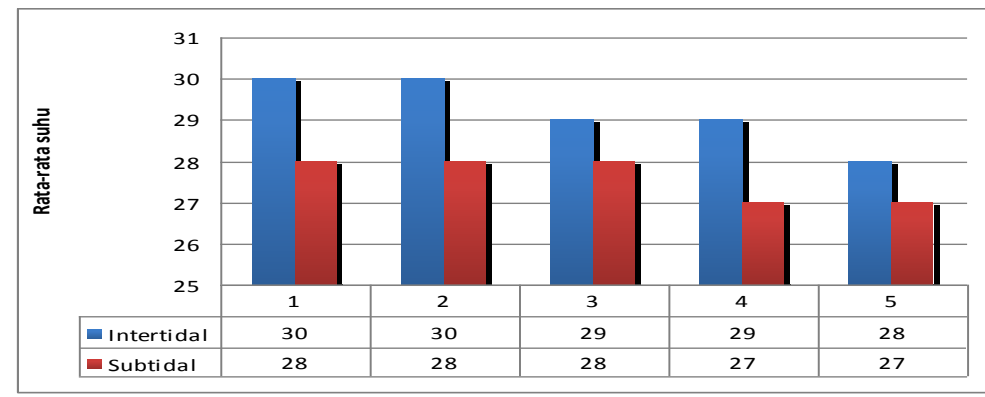

Gambar 1. Profil Suhu Air Laut di Perairan Pantai Desa Suli

\section{Salinitas}

Hasil pengukuran salinitas air laut pada zona intertidal menunjukkan kisaran antara 29 - 30\% sedangkan pada zona subtidal berkisar antara 32- $33 \%$.
Perbandingan rata-rata pengukuran salinitas air laut pada zona intertidal dan zona subtidal di perairan pantai Desa Suli dapat dilihat pada Gambar 2.

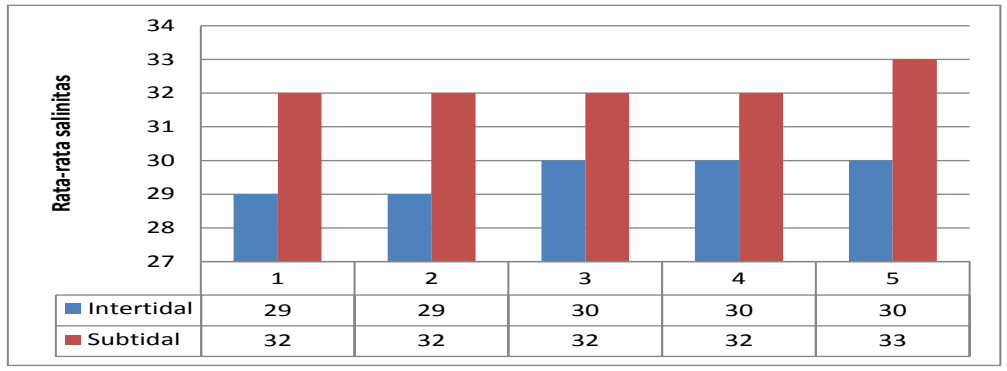

Gambar 2 Profil Salinitas Air Laut di Perairan Pantai Desa Suli 


\section{3. $\mathbf{p H}$}

Parameter kualitas perairan lainnya yang diukur dalam penelitian ini adalah $\mathrm{pH}$ yang diukur pada setiap plot pengamatan diletakan sepanjang garis transek. Hasi pengukuran $\mathrm{pH}$ air laut pada zona intertidal berkisar antara $7-7,6$ sedangkan pada zona subtidal berkisar antara $7,9-8$.

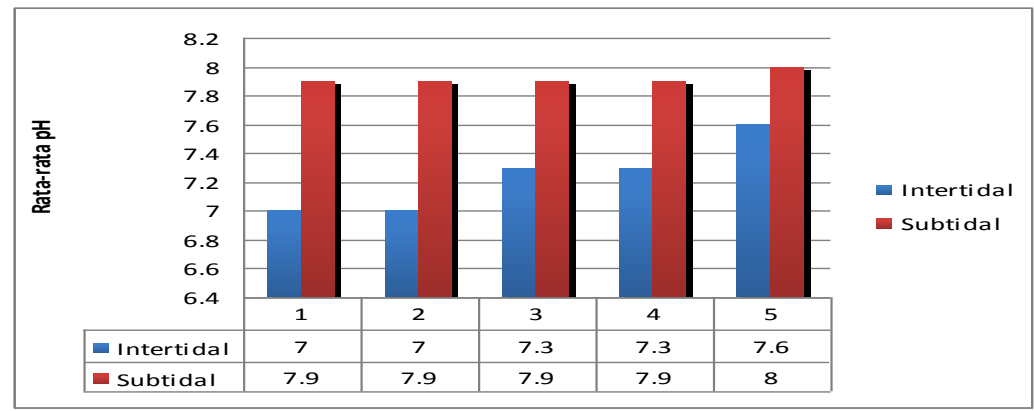

Gambar 3 Profil pH Air Laut di Perairan Pantai Desa Suli

\section{Tingkat Kecerahan.}

Parameter kualitas perairan menunjukkan bahwa tingkat kecerahan air lainnya yang juga digunakan dalam laut berkisar antara 0,5 - $1 \mathrm{~m}$ sedangkan penelitian ini adalah tingkat kecerahan. pada zona subtidal berkisar antara 1 - 1,6 Tingkat kecerahan diukur dengan m. Perbandingan tingkat kecerahan air mengetahui tingkat kedalaman air laut laut pada zona intertidal dan zona subtidal yang dapat dijangkau oleh cahaya pada perairan pantai Desa Suli dapat matahari. Hasil pengukuran tingkat dilihat pada Gambar 4.

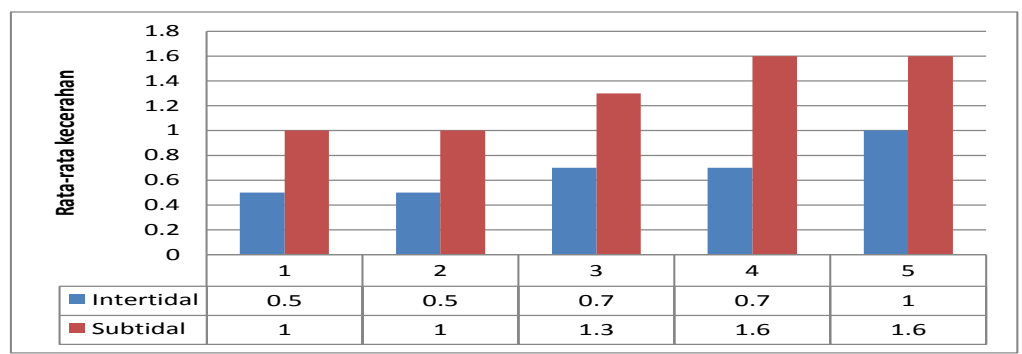

Gambar 4. Profil Tingkat Kecerahan Air Laut di Perairan pantai Desa Suli 
5. Indeks Keanekaragaman (diversity index) Lamun di Perairan Pantai Desa suli.

Hasil identifikasi menunjukkan bahwa terdapat 7 jenis lamun di peraian pantai Desa Suli. Jenis-jenis lamun yang ditemukan di peraian pantai Desa Suli tergolong dalam 6 genus yaitu Cymodocea, Halodule, Syringodium, Enhalus, Thalasia dan Halophila. Jika diurutkan pada tingkatan famili maka ketujuh jenis lamun yang ditemukan dapat digolongkan pada 2 famili yaitu Potamogetonaceae dan Hydrocharitaceae. 7 jenis yaitu: Cymodocea serrulata, Cymodoceae rotundata, Enhalus acoroides, Halodule uninervis, Halophila ovalis, Thalasia hemprichii, dan Syringodium isoetifolium. Urut-urutan taksonomi jenis lamun yang ditemukan di peraian pantai Desa Suli disajikan pada Tabel 1.

Tabel 1. Jenis-jenis Lamun pada Zona Intertidal dan zubtidal

\begin{tabular}{|c|c|c|c|c|c|c|}
\hline $\begin{array}{l}\text { King } \\
\text { dom }\end{array}$ & Divisi & Kelas & Subkelas & Famili & Genus & Spesies \\
\hline \multirow{7}{*}{$\begin{array}{l}\text { Plant } \\
\text { ae }\end{array}$} & \multirow{7}{*}{$\begin{array}{c}\text { Anthoph } \\
\text { yta }\end{array}$} & \multirow{7}{*}{$\begin{array}{l}\text { Angiosper } \\
\text { mae }\end{array}$} & \multirow{7}{*}{$\begin{array}{c}\text { Monocotyle } \\
\text { donae }\end{array}$} & \multirow{4}{*}{$\begin{array}{c}\text { Potamogeton } \\
\text { aceae }\end{array}$} & \multirow{2}{*}{ Cymodocea } & C. rotundata \\
\hline & & & & & & C. serulata \\
\hline & & & & & Halodule & H.uninervis \\
\hline & & & & & Syringodium & S. isoetifolium \\
\hline & & & & \multirow{3}{*}{$\begin{array}{l}\text { Hydrocharita } \\
\text { ceae }\end{array}$} & Enhalus & E. acoroides \\
\hline & & & & & Thalasia & T. hemprichii \\
\hline & & & & & Halophila & H. ovalis \\
\hline
\end{tabular}

Data perhitungan keanekaragaman lamun pada lokasi pengamatan di perairan pantai desa Suli dapat dilihat pada pada Tabel 2

Tabel 2. Indeks Keanekaragaman Lamun di Perairan Pantai Desa Suli

\begin{tabular}{|c|c|}
\hline Stasiun & Indeks Keanekaragaman \\
\hline I (Zona intertidal) & 1,45 \\
\hline II (Zona subtidal) & 1,22 \\
\hline Perairan Pantai Desa Suli & 1,53 \\
\hline
\end{tabular}

Hasil perhitungan menunjukan bahwa zona intertidal memiliki nilai indeks keragaman sebesar 1,45 dan zona subtidal memiliki nilai indeks keragaman relatif lebih rendah sebesar 1,22. 
6. Hubungan Antara Faktor Fisika Kimia (Suhu, Salinitas, dan pH air laut) Lingkungan dengan Keanekaragaman Lamun (Seagrass) di Perairan Pantai Desa Suli.

Berdasarkan hasil uji asumsi berganda selengkapnya dapat dapat dilihat memperlihatkan bahwa ada hubungan pada Tabel 3 .

Tabel 3. Hasil Analisa Regresi Linier Berganda

\begin{tabular}{|c|c|c|c|c|c|c|}
\hline Model & R & R Square & $\begin{array}{c}\text { Adjusted } \\
\text { R Square }\end{array}$ & $\begin{array}{c}\text { R Square } \\
\text { Change }\end{array}$ & F Change & Sig. F Change \\
\hline 1 & $.766(\mathrm{a})$ & .587 & .570 & .587 & 33.742 & .000 \\
\hline
\end{tabular}

Predictors: (Constant), Kecerahan air laut, $\mathrm{pH}$ air laut, Suhu air laut, Salinitas air laut

Hasil analisis regresi linier Besarnya pengaruh variabelberganda yang teringkas pada Tabel 3 menunjukkan bahwa koefisien korelasi secara simultan variabel suhu air laut, salinitas air laut, $\mathrm{pH}$ air laut dan kecerahan air laut adalah sebesar $\mathrm{R}=0,770$ dengan tingkat signifikansi koefisien regresi sebesar 0,00. Hal ini menggambarkan bahwa terdapat hubungan simultan yang signifikan antara setiap variabel bebas dengan variabel terikat. Hasil ini memberikan gambaran bahwa model persamaan regresi dapat digunakan untuk memprediksi keanekaragaman lamun.

yang linear antara setiap variabel bebas dengan variabel terikat sehingga memenuhi asumsi penggunaan analisis regresi berganda. Hasil uji regresi 
Tabel 4. Ringkasan Koefisien Regresi setiap Variabel Bebas

\begin{tabular}{|l|l|r|r|r|r|}
\hline \multirow{2}{*}{ Model } & & \multicolumn{1}{c|}{$\begin{array}{c}\text { Unstandardized } \\
\text { Coefficients }\end{array}$} & $\begin{array}{c}\text { Standardized } \\
\text { Coefficients }\end{array}$ & \multirow{2}{*}{$\mathrm{t}$} & \multirow{2}{*}{ Sig. } \\
\cline { 3 - 5 } & & $\mathrm{B}$ & \multicolumn{2}{c|}{ Beta } & \\
\hline 1 & (Constant) & -8.064 & & -3.286 & .001 \\
\hline & Suhu air laut & .155 & .344 & 2.512 & .014 \\
\hline & Salinitas air laut & -.213 & -.745 & -2.884 & .005 \\
\hline & pH air laut & 1.596 & 1.531 & 5.824 & .000 \\
\hline & Kecerahan air laut & -1.196 & -1.058 & -5.537 & .000 \\
\hline
\end{tabular}

Berdasarkan hasil uji regresi yang laut akan diikuti dengan menurunnya tertera pada Tabel 4, diketahui bahwa keanekaragaman lamun sebesar 0,213. terdapat hubungan yang signifikan antara Selanjutnya, jika ada penambahan 1 variabel suhu, salinitas, $\mathrm{pH}$, dan kecerahan satuan pada variabel $\mathrm{X} 3(\mathrm{pH})$ air laut dengan keanekaragaman lamun di maka akan diikuti dengan meningkatkan perairan pantai Desa suli. Selanjutnya keanekaragaman lamun sebesar 1,596 dan kofisien regresi setiap variabel bebas jika ada peningkatan 1 satuan pada dimasukan ke dalam persamaan regresi berganda $\mathrm{Y}=\mathrm{aX} \mathrm{X}_{1}+\mathrm{aX} 2+\mathrm{aX} 3+\mathrm{aX} 4+\mathrm{K}$, variabel X4 juga akan diiukuti dengan menurunnya keanekargaman lamun dimana $\mathrm{a}=$ koofisien regresi variabel bebas dan $\mathrm{k}=$ konstanta. Dengan demikian diperoleh persamaan regresi $\mathrm{Y}=$ $0,155_{\mathrm{X} 1}-0,213 \mathrm{X} 2_{2}+1,596 \mathrm{X} 3-1,196 \mathrm{X} 4-$ 8,064 . Persamaan regresi ini dapat diartikan bahwa setiap perubahan 1 satuan pada variabel suhu air laut maka diikuti dengan meningkatknya keanekaragaman lamun sebesar 0,155. Demikian pula dengan variabel salinitas air laut, jika terjadi penambahan 1 satuan salinitas air sebesar 1,196.

\section{Sumbangan Relatif dan Sumbangan Efektif Masing-masing Faktor Fisik Kimia Lingkungan terhadap Keanekaragaman Lamun di Perairan Pantai Desa Suli.}

Berdasarkan hasil analisis dapat diketahui sumbangan relatif dan efektif dari setiap faktor fisik kimia terhadap keanekaragaman lamun di perairan pantai desa Suli. Data ringkasan hasil perhitungan dapat dilihat pada Tabel 5.

Tabel 5. Ringkasan Hasil Analisis Sumbangan Relatif dan Efektif Faktor Fisik Kimia

\begin{tabular}{|c|l|c|c|c|c|c|}
\hline \multirow{2}{*}{ No. } & \multirow{2}{*}{ Sumbangan } & \multicolumn{4}{|c|}{ Variabel Bebas } & \multirow{2}{*}{ Total } \\
\cline { 3 - 6 } & & $\begin{array}{c}\text { Suhu } \\
(\boldsymbol{\%})\end{array}$ & $\begin{array}{c}\text { Salinitas } \\
(\mathbf{\%})\end{array}$ & $\begin{array}{c}\mathbf{p H} \\
\mathbf{( \% )}\end{array}$ & $\begin{array}{c}\text { Kecerahan } \\
(\boldsymbol{\%})\end{array}$ & \\
\hline 1. & Relatif & 27,91 & 22,27 & 16,08 & 33,73 & 100 \\
\hline 2. & Efektif & 16,38 & 13,08 & 9,44 & 19,80 & 58,7 \\
\hline
\end{tabular}


Tabel 5 menunjukkan bahwa sumbangan relatif variabel suhu terhadap keanekaragaman lamun adalah sebesar $27,91 \%$, variabel salinitas sebesar 22,27\%, variabel $\mathrm{pH}$ sebesar $16,08 \%$ dan variabel kecerahan 33,73\%. Hasil ini memberikan gambaran bahwa kecerahan merupakan faktor fisik kimia lingkungan yang memberikan sumbangan relatif terbesar terhadap keanekaragaman lamun. Sedangkan sumbangan efektif terbesar terhadap keanekaragaman lamun di perairan pantai desa Suli adalah faktor kecerahan air laut dengan nilai sebesar $19,80 \%$, kemudian diikuti dengan variabel suhu sebesar 16,38\%, variabel salinitas sebesar 13,08\%, sedangkan $\mathrm{pH}$ merupakan faktor fisik kimia lingkungan yang memberikan sumbangan efektif yang paling rendah yaitu 9,44\%. Jika keseluruhan sumbangan efektif setiap variabel bebas dijumlahkan, maka akan didapatkan hasil yang sejalan dengan penerapan SPSS yaitu bahwa model regresi yang digunakan dapat menjelaskan $58,7 \%$ dari perubahan keanekaragaman lamun di perairan pantai Desa Suli.

\section{PEMBAHASAN}

\section{Faktor Suhu.}

Nybaken 1993 mengatakan bahwa kisaran suhu optimal bagi jenis lamun untuk pertumbuhan adalah $28-30{ }^{0} \mathrm{C}$, sedangkan untuk fotosintesis lamun membutuhkan suhu optimum antara 25 $35{ }^{0} \mathrm{C}$ dan pada saat cahaya penuh. Berdasarkan pernyataan ini, maka hasil penelitian yang menunjukan bahwa suhu perairan di semua lokasi pengamatan yang berkisar antara 27-30 ${ }^{0} \mathrm{C}$ masih dalam kisaran suhu optimal untuk pertumbuhan lamun. Hal ini berarti bahwa suhu perairan pantai Desa Suli cocok bagi pertumbuhan dan penyebaran lamun. Kinne dalam Amran (2007) bahwa suhu perairan menentukan kehadiran jenis organisme perairan, mempengaruhi aktivitas pertumbuhan atau bahkan dapat menghambat pertumbuhan yang optimal, setiap jenis mempunyai batas toleransi yang berbeda-beda terhadap suhu terendah dan tertinggi. Hasil penelitian yang menunjukkan bahwa terdapat 7 jenis lamun di perairan pantai Desa Suli menggambarkan bahwa jenis-jenis lamun yang ditemukan memiliki kisaran toleransi yang sama dengan kondisi lingkungan pada perarairan pantai Desa suli. 


\section{Fakor Salinitas}

Hasil analisis regresi berganda yang menunjukkan bahwa koefisien regresi variabel salinitas air laut sebesar 0,213 dengan tingkat signifikansi sebesar 0,005. Dengan demikian dapat disimpulkan bahwa perubahan tingkat keanekaragaman lamun dapat diprediksi dengan variabel salinitas air laut. Kinne (1963) bahwa efek perubahan salinitas dapat mempengaruhi derajat kelangsungan hidup dan pertumbuhan organisme yang berada pada suatu tempat dimana organisme tersebut menetap. Hasil penelitian menunjukkan bahwa semakin menjauhi garis pantai, salinitas air laut akan semakin meningkat, dimana peningkatan salinitas laut juga diikuti dengan menurunnya keanekaragaman lamun. salinitas di laut dipengaruhi oleh berbagai faktor seperti pola sirkulasi air, penguapan, curah hujan dan aliran air sungai. Salinitas bersifat lebih stabil di lautan terbuka, walaupun di beberapa tempat, salinitas menunjukan adanya fluktuasi perubahan. Perairan pantai Desa Suli merupakan tipe pantai tertutup yang berhadapan langsung dengan Laut Banda sehingga sering mendapat pengaruh faktor-faktor lingkungan.
Pengukuran salinitas air laut pada perairan pantai Desa Suli menunjukkan bahwa salinitas air laut berkisar antara 29 - 30\%o pada zona intertidal. Salinitas yang rendah pada zona intertidal disebabkan oleh adanya pengaruh aliran masa air dari sungai yang ada di sekitar lokasi tersebut. sedangkan pada zona subtidal, salinitas air laut berkisar antara 32 - 33\%o. Jika dibandingkan dengan tingkat keanekaragaman lamun pada kedua zona, keanekargaman lamun yang lebih tinggi terdapat pada zona intertidal dibandingkan dengan zona subtidal yang relatif lebih rendah. Gambaran ini memperlihatkan bahwa pada daerah yang salinitas air lautnya lebih rendah, keanekaragaman lamun lebih tinggi sedangkan pada daerah yang salinitas air laut yang lebih tinggi, tingkat keanekaragaman lamun lebih rendah.

Fenomena ini sesuai dengan pendapat Dahuri (1996) yang menyatakan bahwa jenis-jenis lamun memiliki toleransi yang berbeda-beda, namun sebagian besar memilki kisaran yang lebar yaitu 10 - 4\%o. Hilman et al dalam Zulkifli (2003) mengatakan bahwa pertumbuhan lamun membutuhkan salinitas optimum berkisar 24 - 30\%o sedangkan untuk fase 
pembungaan kisaran salinitas yang baik adalah antara 28 - $32 \%$ (Marmelstein et al dalam Zulkifli 2003). Berdasarkan pernyataan ini, maka hasil penelitian yang menunjukan bahwa salinitas perairan di lokasi pengamatan yang berkisar antara 27 - 30\%o masih dalam kisaran salinitas yang optimal untuk pertumbuhan lamun. Hal ini berarti salinitas perairan pantai Desa Suli cocok bagi pertumbuhan dan penyebaran lamun.

\section{Faktor pH}

Hasil analisis regresi berganda menunjukkan bahwa terdapat hubungan yang signifikan antara $\mathrm{pH}$ dan keanekaragaman lamun di perairan pantai Desa Suli, dan dapat digunakan untuk memprediksi perubahan pada variabel keanekaragaman lamun. Hasil penelitian ini juga menunjukkan bahwa semakin menjauhi garis pantai $\mathrm{pH}$ air laut akan semakin meningkat dan peningkatan $\mathrm{pH}$ air laut diikuti dengan menurunnya tingkat keanekaragaman lamun. Menurut Philips dan Menez dalam Zulkifli (2003) nilai derajat keasaman $(\mathrm{pH})$ optimum untuk pertumbuhan lamun adalah berkisar 7,3 9,0. Berdasarkan pernyataan ini, maka hasil penelitian yang menunjukan bahwa $\mathrm{pH}$ perairan di semua lokasi pengamatan pada perairan pantai Desa Suli yang berkisar antara 7 - 8 masih dalam kisaran pH optimal untuk pertumbuhan lamun.

Hasil analisis regresi menunjukkan bahwa koefisien regresi $\mathrm{pH}$ air laut adalah signifikan dan dapat digunakan untuk memprediksi perubahan tingkat kemerataan lamun di perairan pantai Desa Suli. Derajat keasamaan atau $\mathrm{pH}$ merupakan parameter kimia yang menunjukkan konsentrasi ion hidrogen pada perairan. Konsentrasi ion hidrogen tersebut dapat mempengaruhi reaksi kimia yang terjadi di lingkungan perairan. Menurut Philips dan Menez (1988) kisaran normal pH air laut adalah 7,8-8,2. Dijelaskan lebih lanjut bahwa derajat keasaman $(\mathrm{pH})$ perairan sangat dipengaruhi oleh dekomposisi tanah dan dasar perairan serta keadaan lingkungan sekitarnya. Selain hubungannya dengan kemerataan, analisis juga dilakukan untuk melihat hubungan $\mathrm{pH}$ dengan indeks kekayaan lamun. Hasil analisis memperlihatkan menunjukkan bahwa koefisien regresi variabel $\mathrm{pH}$ adalah signifikan dan dapat digunakan untuk memprediksi kekayaan lamun. Dengan demikian dapat disimpulkan bahwa $\mathrm{pH}$ merupakan faktor pembatas bagi 
penyebaran lamun pada perairan pantai Desa Suli.

\section{Tingkat Kecerahan}

Hasil analisis regresi berganda juga menunjukkan bahwa signifikansi koefisien regresi variabel tingkat kecerahan adalah bermakna pada taraf signifikansi 0,05 sehingga dapat digunakan untuk memprediksi perubahan tingkat keanekeragaman lamun di perairan pantai Desa Suli. Supriharyono (2007) menyatakan bahwa penetrasi cahaya matahari atau kecerahan adalah penting bagi tumbuhan lamun. Lebih lanjut dijelaskan bahwa tumbuhan lamun biasanya tumbuh di laut yang sangat dangkal karena membutuhkan cahaya yang sangat banyak untuk mempertahankan populasinya. Randal dalam Supriharyono (2007) mengemukakan bahwa Thalassia testudium dapat tumbuh hingga mencapai kedalaman 13 m, sedangkan Cymodocea monatorium dapat tumbuh hingga kedalaman $22 \mathrm{~m}$ tetapi pada umumnya kedalaman maksimum bagi pertumbuhan lamun adalah 10 m (Dawes, 1981).

Perbedaan kemampuan lamun untuk tumbuh pada kedalaman yang berbeda disebabkan oleh saturasi cahaya setiap individu lamun. Hasil penelitian ini menunjukkan bahwa tingkat kecerahan air laut pada plot-plot di kedalaman yang lebih dangkal akan lebih rendah jika dibandingkan dengan plot-plot yang diletakan pada kedalaman air laut yang lebih tinggi. Hal ini disebabkan karena adanya kekeruhan yang diakibatkan oleh suspensi sedimen dapat menghambat penetrasi cahaya. Dijelaskan oleh Hilman et.al dalam Zulikifly (2003) bahwa untuk perairan dangkal, lamun terhambat pada level $150-250 \mu \mathrm{nol} / \mathrm{m}^{2} / \mathrm{det}$, dan yang hidup di perairan dalam terhambat pada level kurang dari $\mu \mathrm{nol} / \mathrm{m}^{2} /$ det.

Hal ini menggambarkan status dari perairan ini masih cukup baik, artinya ada tekanan ekologis dari aktivitas masyarakat pesisir di sekitar padang lamun namun volumenya rendah dan belum terlalu berbahaya bagi kelangsungan ekosistem padang lamun di perairan pantai Desa Suli. Meskipun demikian aktivitas masyarakat untuk mengeksploitasi sumbedaya di padang lamun harus dibatasi karena secara perlahan-lahan akan mengancam kelestarian padang lamun dan sumberdaya yang ada di dalamnya. 


\section{KESIMPULAN}

1. Tingkat keanekaragaman lamun di perairan pantai Desa Suli tergolong sedang. Pada zona intertidal ideks keanekaragaman sebesar $\quad 1,45$ sedangkan pada zona subtidal indeks keanekaragamannya lebih rendah sebesar 1,22. Kondisi faktor fisik kimia lingkungan (suhu berkisar antara $27-30^{\circ} \mathrm{C}$, salinitas berkisar antara $29-33 \%, \mathrm{pH}$ berkisar antara 7 - 8,4 dan tingkat kecerahan air laut 0,5

- $6 \mathrm{~m}$ ) di perairan pantai Desa Suli cukup mendukung pertumbuhan dan penyebaran lamun serta biota yang ada di dalamnya.

2. Berdasarkan hasil ANAREG linear berganda terdapat hubungan yang signifikan secara simultan antara fakor fisik kimia lingkungan (suhu, salinitas, $\mathrm{pH}$ dan tingkat kecerahan air laut) dengan keanekaragaman lamun di perairan pantai Desa Suli. Faktor fisik kimia lingkungan perairan yang memberikan sumbangan effektif tertinggi terhadap keanekaragaman lamun adalah faktor kecerahan air laut.

\section{DAFTAR PUSTAKA}

Krebs, C.J. 1989. Ecology of experimental analysis of distribution and abudance. Second Edition. Harper and Row Publisher. New York

Dahuri, R. 2003. Keanekaragaman Hayati Laut Aset Pembangunan Berkelanjutan. Gramedia Pustaka Utama. Jakarta.

Heddy, S. 1994. Prinsisp-prinsip Dasar Ekologi. Penebar Swadaya. Jakarta:

Hutomo, M. 1985, Peranan lamun di Lingkungan Laut Dangkal, Oseana Vol.XII.

Indriyanto. 2006. Ekologi Hutan. Bumi Aksara. Jakarta

Kartawinata, K. 1992. Konservasi sumberdaya Tanah dan Air. Kalam Mulia. Jakarta:

Nybakken, J. W. 1992. Biologi Laut Suatu Pendekatan Ekologis. Gramedia. Jakarta

Odum, E.P. 1996. Dasar-dasar Ekologi. Universitas Gadjah Mada. Yogyakarta:

Phillips, R.C. \& Menez, 1988. Seagrass. Institutions Press. Washington D.C Mith Sonian.

Sheppard, C., A. Price. \& C. Roberts 1996. Marine ecology of the Arabian Region. Patterns and processes in extreme tropical environment. Academic Press, Harcourt Brace Johanovich, Publisher. London

Short, F. \& P. Pergent-Mantini. 2001. Global Seagrass Disstribution In Global Seagrass Research Methods, edited by F.T. Short and R. G. Elsevier Science B. V. 